\title{
П.М. Канило
}

\section{ЛЕДНИКОВЫЕ ЭПОХИ И ГЛОБАЛЬНОЕ ПОТЕПЛЕНИЕ КЛИМАТА}

\begin{abstract}
Приводятся краткие исторические аспекты изучения ледниковых эпох, изменений климата Земли и рождения астрономической теории. Отмечается, что современный межледниковый период по астрономическим канонам должен заканчиваться в ближайшем тысячелетии и начинаться похолодание. Однако, примерно с 1970 г., на Земле происходит глобальное потепление климата. В статье обосновывается вывод, что современное потепление климата - это антропогенная экологическая реальность, связанная с резким увеличением численности человечества и его хишническим отношением к ПРИРОДЕ, существенным повышением уровней неэффективного использования природных ресурсов и предельно опасным загрязнением среды жизни супертоксикантами, с деградацией, разрушением и уничтожением систем биосферы, включая глобальную биоту, и приводящзи, соответственно, к снижению качества их функционирования, в том числе, биопродуктивности, средообразующих и климатостабилизирующих функций.
\end{abstract}

\section{Введение}

В настоящее время три экологические проблемы обосновано привлекают внимание: глобальное потепление климата на Земле, судьба озонового слоя в стратосфере, замкнутость глобальных биогеохимических круговоротов (концепция биотической регуляции окружающей среды). Парадокс состоит в том, что, несмотря на обоснованную в научной литературе первичность третьей из этих проблем и вторичность двух других, отсутствует понимание концептуально важного обстоятельства, в котором основополагающее значение имеет последовательность событий: социальноэкономическое развитие (стимулируемое ростом численности населения планеты), антропогенноэкологическое воздействие на биосферу и последствия подобных воздействий на окружающую среду (климат, озоновый слой и т.д.). За последние 45 лет среднеглобальная среднегодовая приземная температура воздуха (ССПТВ) повысилась примерно на $1^{\circ} \mathrm{C}$, что сопровождается таянием ледников и повышением уровня Мирового океана. Однако, до настоящего времени нет однозначности в понимании определяющих причин современного потепления климата и возможностей человечества в решении этой глобальной проблемы. Существуют также неопределенности в прогностических оценках этого явления, в том числе, по изменению подвижного баланса между естественными уровнями эмиссии в атмосферу парниковых газов (ПГ), в первую очередь диоксида углерода $\left(\mathrm{CO}_{2}\right)$, и его стоками. При этом одна из важных нерешенных составляющих состоит в отсутствии надежных количественных оценок вклада антропогенных факторов в формирование глобального климата. Особого внимания требует дальнейшее развитие исследований глобального круговорота углерода, имея в виду нерешенность проблемы «потерянного стока» $\mathrm{CO}_{2}$, который обусловлен, в том числе, уменьшением эффективности и продуктивности функционирования деградируемых и уничтожаемых фотосинтезирующих систем суши и Мирового океана, включая снижение их регуляторных и климатостабилизирующих функций. Ранее, не уни- чтоженные леса только России аккумулировали $1200 \cdot 10^{9}$ т $\mathrm{CO}_{2}$ в год, т.е. в 30 раз больше, чем уровни эмиссии $\mathrm{CO}_{2}$ при сжигании всех топлив на Земле. Современное потепление климата - это кризис варварской, по отношению к ПРИРОДЕ, технократической цивилизации, это кризис социальнодемографический. При дальнейшем повышении ССПТВ возможны отрицательные последствия: усиление испарения вод Мирового океана и дальнейшая интенсификация парникового эффекта, охлаждение стратосферы и соответствующее утончение защитного озонового экрана, поднятие уровня Мирового океана и затопление прибрежных зон, где проживает более $60 \%$ населения планеты. Всемирный фонд дикой природы (WWF) прогнозирует, что к концу XXI века уровень океанов поднимется более, чем на метр. Специалисты прогнозируют: Мировой океан и его побережья входят в новую климатическую фазу. В последние годы шапка арктических льдов тает в три раза быстрее, чем 20 лет назад. Такие данные приводит Национальное управление океанических и атмосферных исследований США в ежегодном «Отчете о состоянии Арктики». На международно-политическом уровне проблему глобального потепления климата на Земле пытались и пытаются решать путем замены естественных природных стабилизаторов климата - искусственными, т.е. техносферой, что является безнадежным и лишено здравого смысла. При этом, однако, следует особо отметить основное отличие результатов последнего климатического саммита, проведенного в предместье Парижа (декабрь 2015 г.), - произошел сдвиг в геополитическом восприятии глобального потепления климата на Земле. От предостережения о рисках в далекой перспективе оно превратилось в актуальную современную угрозу для человечества.

Краткая историческая справка по изучению тайн ледниковых эпох

Существенным дополнением теоретических исследований и численного моделирования климата на Земле продолжает оставаться изучение колебаний климата, наблюдавшихся в прошлом как образцы будущих изменений. ССПТВ Земли за 
последние 100 млн. лет по сравнению с современными значениями существенно изменилась (рис. 1, [1]). Колебательный характер изменения ССПТВ $\left(\Delta t_{\mathrm{B}}\right)$ отражал временные потепления и похолода- ния климата на Земле. Однако на фоне этих колебаний четко видна основная тенденция - развивающееся похолодание.

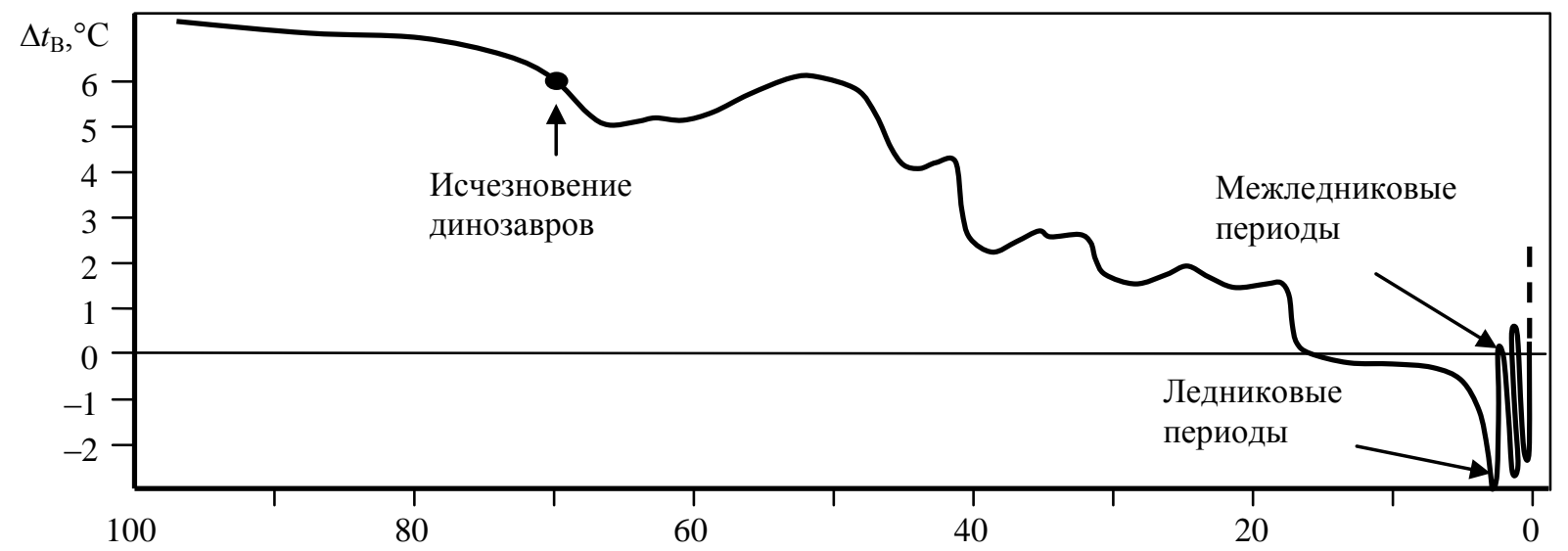

Рис. 1. Изменение глобальной температуры в последние 100 млн. лет относительно средней за 19611990 гг. (Информационные материалы. ЮНЕП/ОИК, Женева, 1997 г.)

Следует отметить, что известные температурные пределы существования жизни (растения сохраняют жизнеспособность в пределах от $0{ }^{\circ} \mathrm{C}$ до $\left.60{ }^{\circ} \mathrm{C}\right)$ позволяют утверждать, что уровни ССПТВ в истории жизни на Земле (за последние 30 млн. лет) отличались от современных условий не более, чем

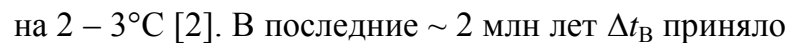
резко колебательный характер с амплитудой $\sim 3^{\circ} \mathrm{C}$. Это и есть плейстоцен с развитием покровных оледенений, когда холодные фазы разрастания грандиозных ледниковых щитов сменялись более короткими теплыми межледниковыми периодами [3]. Климатическая история Земли за последние 500 тыс. лет характеризовалась чередованием ледниковых периодов, продолжавшихся 100 тыс. лет, включая короткие теплые межледниковые периоды, длительностью не более 12 тысяч лет. Еще 20 тысяч лет назад часть планеты Земля пребывала в жестких объятиях ледникового периода. Гигант- ские массы льда, получавшие непрерывное пополнение из арктических бастионов холода, медленно наступали на юг, безжалостно погребая под собой леса, равнины и горы. Уровень Мирового океана снижался ( на 100 метров). И, тем не менее, последнее оледенение пришло к концу. Около 14 тыс. лет назад ледниковые покровы суши стали заметно сокращаться и за последующие несколько тысяч лет достигли своих современных размеров. В Северном полушарии их остатки сегодня представлены лишь Гренландским ледниковым щитом и небольшим числом ледниковых шапок Канадской и Евразийской Арктики. Ледниковые покровы отступили и исчезли, ушли они и из памяти людей. Примерно 10 тыс. лет назад началось потепление климата. Наступивший межледниковый период называют голоценом. Колебания ССПТВ до 1970 г. происходило в пределах $\pm 1{ }^{\circ} \mathrm{C}$ (рис. 2, [1]).

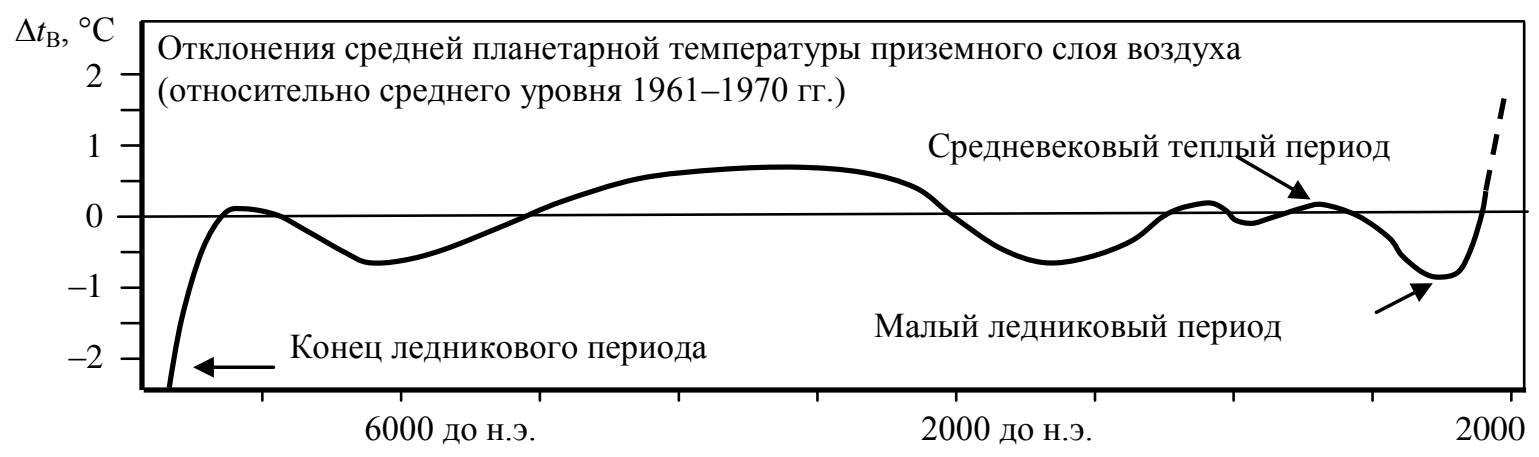

Рис. 2. Изменение ССПТВ в голочене

(Информационные материалы. ЮНЕП/ОИК, Женева, 1997 г.)

Еще в XVIII столетии новой эры геологи верили, что покров грубых несортированных «нано- сов», выстилавших сушу во многих районах Сeверной Европы и Америки, возник во время биб- 
лейского Всемирного потопа. И лишь в начале XIX века появились ученые, которые усомнились в правильности такого объяснения. В 1837 г. на конференции Швейцарского общества естествоиспытателей молодой ученый Луи Агассис (президент общества) высказал «еретическую» гипотезу о ледниковом периоде в истории Земли. Начался околонаучный спор, ставший одним из самых ожесточенных в истории геологической науки. Он продолжался $\sim 40$ лет и завершился все-таки признанием существовавшей на тот период ледниковой теории, включая неоднократность древних оледенений, но без научно-фактического базиса доказательств ледниковых эпох [4].

\section{Рождение астрономической теории}

B XVI веке польский ученый Николай Коперник изложил новую гелиоцентрическую систему мира, в которой Земля и другие планеты Солнечной системы движутся вокруг Солнца. Идея, что в роли главных возбудителей древних оледенений могли выступать изменения в закономерном ходе обращения Земли вокруг Солнца, принадлежит французскому математику Жозефу Альфонсу Адемару (1842 г.). Затем последовали научные дополнения к астрономической теории математика Жана Ленера Д'Аламбера и немецкого географа А. Гумбольда. Идею Жозефа Адемара подхватил шотландец Джеймс Кролль, который в основу появления оледенений включил изменения: эксцентриситета орбиты движения Земли вокруг Солнца, наклона земной оси вращения и ее прецессии. Но вскоре большое число геологов Европы и Америки разочаровались в теории Д. Кролля. Они увидели ее несоответствие новым данным, по которым последнее оледенение завершилось не 80 тыс. лет (по теории Д. Кролля), а 10 тыс. лет назад. Кроме того, свое слово сказали метеорологи, по расчетам которых изменения инсоляции, постулированное Д. Кроллем, было слишком незначительным, чтобы оказать заметное воздействие на климат планеты.

В начале XX века астрономическая теория возродилась в трудах сербского ученогоматематика Милутина Миланковича. В книге «Астрономические методы исследования истории климата Земли» (1939 г.), а затем в монографии «Канон инсоляции и проблема ледниковых эпох» (1941 г.) он подвел итоги своих исследований, а результаты его многолетних трудов получили международное признание. М. Миланковичем были построены инсоляционные кривые колебаний поступления радиационного тепла для различных широт Северного полушария Земли за последние 500 тысяч лет. Каждому крупному инсоляционному минимуму должна была соответствовать особая ледниковая эпоха. Само ценное в астрономической теории М. Миланковича -ее пригодность для прогнозирования климата прошлого, поддающаяся геологической проверке. Но к концу первой половины XX столетия астрономическая теория М. Миланковича потеряла практически всех ее сторонников. Виновником столь быстрого заката указанной теории стало развитие принципиально нового радиоуглеродного метода абсолютной геохронологии, т.е. нового подхода к проблеме датирования органических останков, извлекаемых из плейстоценовых отложений материков. Уже в 1951 г. с использованием этого метода было показано, что последний ледниковый покров Северной Америки достигал своего максимального распространения $~ 18$ тыс. лет назад, а около 10 тыс. лет назад он быстро деградировал.

Между тем, в осадочных образованиях материков следы древних климатов сохранялись лишь фрагментарно. Одним из первых, кто сумел понять принципиальную неполноту наземной летописи климатов, был Джеймс Кролль. Он же пророчески предсказал: «В глубочайших уголках океанов, захороненные под сотнями футов песка, ила и гравия, нас ждут растительные и животные останки, которые были во множестве вынесены туда реками из суши. А вместе с ними должны покоиться скелеты, раковины и панцири созданий, благоденствовавших тогда в самом океане». Однако, эти предсказательные слова Д. Кролля были лишь плодом абстрактных размышлений. Но океан не мог вечно хранить свои тайны. К концу первой половины XX столетия начались научные исследования осадочных пород на дне океанов. Дно океана оказалось действительно покрыто плащом осадочного материала. Вдали от материков основные площади дна, как выяснилось, были выстланы илами, целиком состоящими из окаменелостей останков мельчайших животных и растений. Образование органогенных илов было связано с длительным процессом выпадения из водной толщи на дно скелетов организмов - типа планктоновых. К этому времени были разработаны и изготовлены ударно-поршневые трубы, с помощью которых можно было брать из дна океанов необходимые «колонки» длиной до 15 метров, что означало новую эру в изучении истории климата Земли. Был предложен метод предсказания температур вод Мирового океана в прошлом по соотношению изотопов кислорода $\delta \mathrm{O}^{18}$ и $\delta \mathrm{O}^{16}$. Оба типа атомов кислорода присутствовали и в известковых скелетах морских организмов. Чем вода холоднее, тем более высоким было содержание тяжелого изотопа кислорода в скелетах. Этот метод стал важнейшим для проверки конкурирующих теорий, выдвинутых для объяснения плейстоценовых ледниковых эпох. 
В начале 70-х годов XX века в США был подготовлен междисциплинарный междуведомственный проект (КЛИМАП), получивший финансовую поддержку из средств, ассигнованных Национальным научным фондом США на программу Международного десятилетия исследований океана. В проекте были задействованы ведущие университеты США и приглашены известные ученые из Европы, в том числе молодой геофизик Николас Шеклтон из Кембриджского университета (Англия), который существенно усовершенствовал методику изотопно-кислородного анализа и теперь можно было делать точные определения по считанному числу особей микрофауны. Началось изучение «колонок» взятых из донных отложений в различных точках Мирового океана. На рис. 3 [4] приведен график относительного содержания стабильных изотопов кислорода в останках планктона на дне океанов, полученный участниками междуведомственного проекта КЛИМАП (1971 г.), отражающий практически относительное изменение суммарного объема ледниковых покровов Земли.

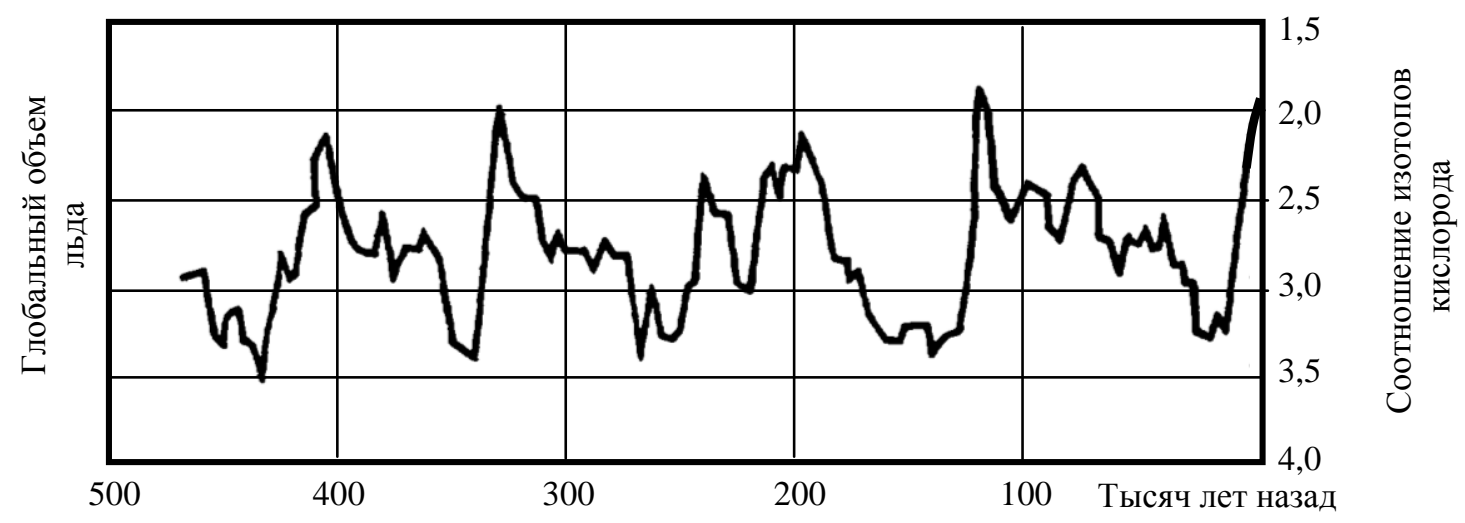

Рис.3. Изменение относительного содержания стабильных изотопов кислорода в останках планктона на дне океанов

В климате Земли последнего полумиллиона лет ясно видны отпечатки циклов, имеющих периоды в 100000, 41000 и 22000 лет, которые были ранее предсказаны астрономической теорией. В течение этого времени на Земле происходили периодические разрастания и резкие сокращения ледниковых покровов. Было подтверждено, что первопричиной ледниковых эпох второй половины плейстоцена действительно служили изменения в эксцентриситете земной орбиты, в наклоне оси вращения Земли и ее прецессии. Джон Имбри в своей книге «Тайны ледниковых эпох» написал: «Правда, конкретные механизмы преобразования слабых «космических сигналов» в глубокие изменения климата Земли и оледенение оставались неизвестными, как были неизвестны и причины, по которым 100000-летние циклы изменений эксцен- триситета орбиты оставили столь сильный отпечаток на всей геологической истории последнего полумиллиона лет. Но это не могло заслонить главного: после многих лет поисков и сомнений мы наконец убедились, что путь к разгадке тайн ледниковых эпох, избранный Милутином Миланковичем, этим «скитальцем по далеким мирам и векам», был правильным». Следует также отметить работу в этот период японского ученого Мотонори Матуяма, который, с помощью палеомагнитного метода, определил возраст плейстоцена, составивший 1,8 млн. лет. На рис. 4 приведен график последнего большого климатического цикла, показывающего, что пульс климата Земли бился в ритме один цикл за 100 тысяч лет и в ближайшее тысячелетие по астрономическим канонам должно начаться похолодание [4].

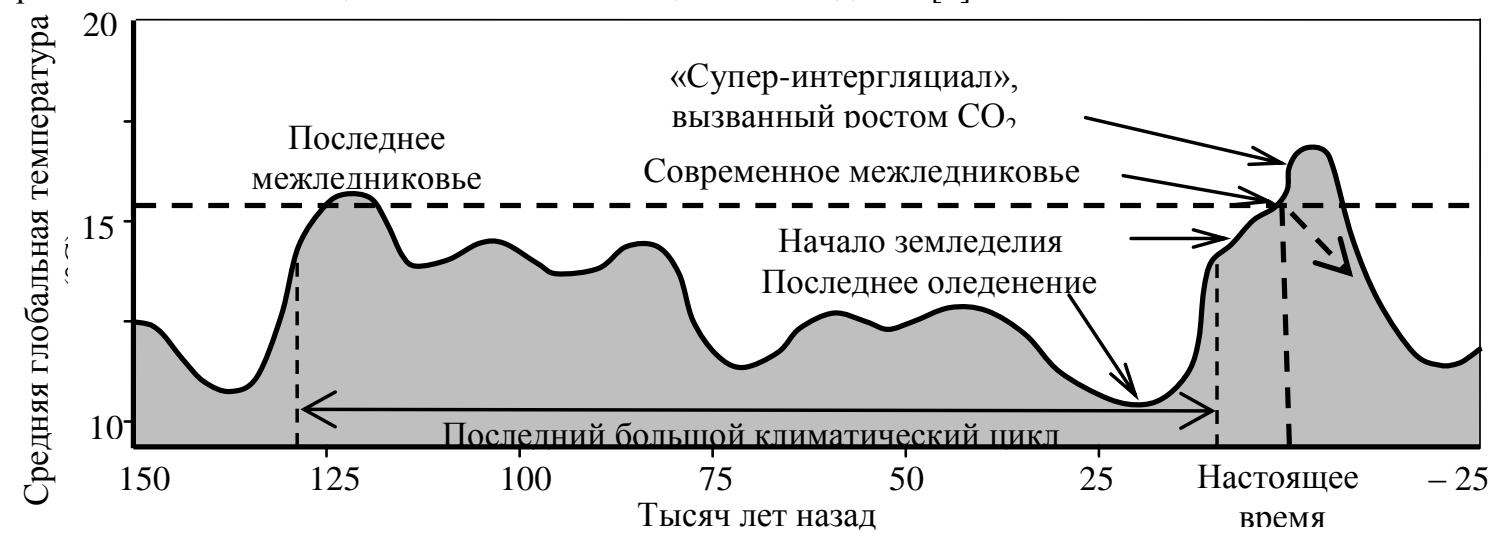

Рис. 4. Последний большой климатический ичикл 


\section{Некоторые концептуальные аспекты кли- матической системы Земли}

1. Климатическая система Земли предельно сложная. Внешние, или астрономические, климатообразующие факторы - это светимость Солнца, положение и движение Земли в Солнечной системе, наклон оси вращения Земли к плоскости орбиты и ее прецессия. Эти факторы определяют, вопервых, уровень инсоляции Земли (облучение солнечной радиацией) и, во-вторых, гравитационное воздействие внешних тел, создающее колебание характеристик орбитального движения и собственного вращения Земли, а потому и колебаний в распределении инсоляции по внешней границе атмосферы. Фактические данные современной астрофизики подтверждают вывод о стабильности светимости Солнца. Солнечная активность может проявляться лишь в колебаниях корпускулярной и жесткой электромагнитной компонент солнечного излучения, несущих очень малую долю от полной энергии Солнца, и вряд ли они могли дать основу для каких-либо выводов о генезисе колебаний климата на планете. Ко второй группе климатообразующих факторов (геофизическим), связанным со свойствами Земли как планеты, относятся: размеры и масса планеты, скорость вращения вокруг оси, собственные гравитационное и магнитное поля, внутренние геотермические источники тепла, свойства поверхности планеты, которые определяют ее взаимодействие $\mathrm{c}$ атмосферой. Геотермический поток тепла в настоящее время практически постоянен, составляет $\sim 0,02 \%$ от ежегодного количества поступающей на поверхность Земли солнечной энергии и он также практически не может значимо влиять на современное потепление климата на Земле. При этом скорость вращения Земли оказывает значимое влияние на характер всей атмосферной циркуляции. Климат Земли зависит также от характеристик каждого из звеньев климатической системы и, в первую очередь, от характеристик атмосферы и гидросферы. Главными метеорологическими климатообразующими факторами являются масса и химический состав атмосферы. Масса атмосферы определяет ее механическую и тепловую инерцию, ее возможности как теплоносителя, способного передавать тепло от нагретых областей к охлажденным. Без атмосферы на Земле существовал бы «лунный» климат, т.е. климат лучистого равновесия. Атмосферный воздух представляет смесь газов, различных жидких и твердых аэрозолей, которые также имеют существенное значение в формировании климата. Неотъемлемой частью климатической системы является Мировой океан, который играет в ней исключительно важную роль, в том числе, являясь емким резервуаром $\mathrm{CO}_{2}$, способным в одних условиях поглощать избыток $\mathrm{CO}_{2}$, а в других - выделять $\mathrm{CO}_{2}$ в атмосферу. При этом вариации климата Земли рассматриваются как интегрально-нестационарные, находящиеся под действием меняющихся со временем внешних и внутренних факторов.

2. Установлено: мощность солнечной радиации, достигающей поверхности земного шара, равна $\sim 120000$, фотосинтеза 130, мощность установок, производящих энергию на Земле, 10 ТВт. Годовая энергия солнечной радиации соответствует $\sim 4 \cdot 10^{12}$ ТДж и превышает годовое производство энергии человечеством ( 4.10 8 ТДж) примерно в 10000 раз. Причем, $90 \%$ энергии производится на Земле за счет сжигания ископаемых топлив и примерно такая же доля массовых уровней супертоксикантов: оксидов азота (NOx) и серы (SOx), твердых частиц (ТЧ), канцерогенных углеводородов (КУ), индикатором наличия последних в окружающей среде (ОС) принят бенз(а)пирен (БП $\mathrm{C}_{20} \mathrm{H}_{12}$ ), выбрасывается с продуктами их сжигания. За последние 50 лет установлено: постоянство солнечной радиации на среднем расстоянии от Земли $\left(\sim 140 \mathrm{BT} / \mathrm{M}^{2}\right)$ и практическое отсутствие влияния других астрономических факторов на уровни изменений солнечной радиации у ее поверхности. Поэтому, практическое постоянство солнечной радиации и относительно небольшие объемы энергопроизводства человечеством в указанный период не могли значимо, а тем более существенно, влиять на современное потепление климата на Земле [5-9].

3. Климатическая система Земли физически имеет только два устойчивых, но безжизненных состояния (типа планет: Венеры или Марса). Но жизнь на Земле существует. Живая материя возникла в воде $\sim 3,5$ млрд. лет тому назад. В процессе эволюции глобальная биота создала механизм фотосинтеза, наполнила атмосферу кислородом, был образован защитный озоновый экран ( $600 \mathrm{Mлн}$ лет тому назад) и жизнь покорила сушу ( 300 млн лет тому назад). В итоге сложилась устойчивая цепь глобальных биогеохимических круговоротов веществ и, что самое главное, был создан уникальный биотический механизм стабилизации климата [2, 10, 11]. Именно глобальная биота превратила Землю в планету, резко отличающуюся от других планет Солнечной системы. Глобальная биота планеты, создавая экосферу и разум, контролировала содержание уровней кислорода и основного парникового газа $-\mathrm{CO}_{2}$ в тропосфере (через изменение объемов и эффективности фотосинтеза, а также степени растворимости их в водах Мирового океана). Кроме того, она обеспечивала регуляцию пар- 
никового эффекта и альбедо Земли, в том числе, изменяя: интенсивность испарения вод Мирового океан (влияя на прозрачность воды путем выделения поверхностно-активных веществ и, таким образом, изменяя степень прогрева более глубоких слоев воды), а также - соотношений $\mathrm{CO}_{2}$, паров и жидких капель воды в тропосфере, т.е. регулируя отражательные и поглощательные свойства атмосферы $[2,11]$. В.И. Вернадский обосновал совершенно новый взгляд на феномен жизни - как фактор геохимической организации планеты.

4. Современное потепление климата - это антропогенно-экологическая реальность. В последнем межледниковье - голоцене - возникли цивилизации и изменение концентраций $\mathrm{CO}_{2}$, как основного парникового газа в тропосфере, пошло совершенно иным путем. В предыдущие межледниковые периоды на климат планеты влияли только природные факторы, они и сейчас продолжают влиять аналогичным образом. Поэтому иной ход изменения концентрации $\mathrm{CO}_{2}$ и ССПТВ в голоцене наиболее естественно объясняется появлением цивилизаций, которые сравнивают с «махровым» цветком, ибо такой живет за счет обеднения окружающей природной среды. «Очеловечиваемая» природа подвергалась интенсивным воздействиям, ведущим к структурно-организационной деградации. Леонардо да Винчи (1452 - 1519 гг.) первым фиксирует антропогенное нарушение природного равновесия. При этом взаимосвязь систем биосферы и цивилизаций превратилась из философской в практическую и вопрос, по какому пути пойдет их совместное развитие, остается открытым. Можно предположить, что неизбежное изменение климата и других природных условий на поверхности Земли явится началом движения к новому глобальному квазиравновесию. Последние 60 лет в истории человечества характеризуются трехкратным увеличением численности населения Земли. Эта «новая геологическая сила» при хищнической коммерчески-неэффективной экономике технократической цивилизации и варварском отношении к ПРИРОДЕ породила десятки суперглобальных проблем, включая: деградацию и разрушение биосферы, значимое сокращение видового разнообразия биоты, масштабное уничтожение лесов, антропогенное опустынивание земель и т.д. Все это, в основном, и привело к разбалансировке климатической системы Земли, т.е. к снижению (или отключению) природных механизмов стабилизации климата, к уменьшению уровней стоков основного парникового газа - $\mathrm{CO}_{2}$ и его накоплению в тропосфере, а, следовательно, к потеплению климата на планете. Потепление климата будет продолжаться в XXI веке, если человечество не поумнеет $[3,5,12-16]$.
5. До настоящего времени нет однозначности в понимании определяющих причин современного потепления климата на Земле и возможностей человечества в решении этой глобальной проблемы. Многие ученые считают, что относительная безуспешность раскрытия тайн глобального потепления климата на Земле объясняется сложностью изучаемой климатической системы и недостаточно полным учетом комплексного влияния на климат планеты таких динамических систем как Мировой океан, атмосфера, криосфера, биосфера, включая элементы биотической регуляции и стабилизации климата планеты, а в настоящее время - воздействий численно увеличившегося человеческого общества [3, 9, 14-16].

6. На мировом политическом уровне уже более двух десятилетий (со времени конференции в Рио-де-Жанейро в 1992 г., где была принята рамочная конвенция по изменению климата) проблематика глобального потепления климата являлась одной из наиболее дискутируемых, которая прочно вытеснила из общественного сознания десятки других суперважнейших проблем человечества. На международно-политическом уровне проблему глобального потепления климата пытаются решать путем замены естественных биотических стабилизаторов климата - искусственными, т.е. техносферой. Политиками неверно установлен диагноз проблемы потепления климата - из-за роста уровней эмиссии индустриальных парниковых газов, который, как будет показано далее, более чем на $90 \%$ не соответствует реальности [8, 9, 14-16]. При этом, этот дезорганизующий политико-техногенный диагноз и решения, направленные как бы на ослабление глобального потепления климата на Земле путем технологического улавливания индустриальных выбросов $\mathrm{CO}_{2}$, был поддержан участниками климатического саммита в Париже. Согласно документу, все подписавшиеся участники (из 196 стран) обязуются сокращать выбросы основного парникового газа $\mathrm{CO}_{2}$ в атмосферу. К 2030 г. Евросоюз намерен сократить указанные выбросы $\mathrm{CO}_{2}$ на $40 \%$, США - на $26 \%$, а Украина - на $40 \%$. К этому можно добавить следующее. По прогнозам Мирового института ресурсов выбросы ПГ в России могут увеличиться к 2030 г. на 40 - $50 \%$ по отношению к 2012 г., тогда как страна обязалась их снизить на 25 - 30 \% по сравнению с 1990 г. Кроме того в соглашении отмечается, что потепление климата не должно превысить $2^{\circ} \mathrm{C}$, а идеале $1,5^{\circ} \mathrm{C}$. Однако ученые прогнозируют рост ССПТВ на $3-4{ }^{\circ} \mathrm{C}$ и утверждают, что проблема изменения климата не в том, что он теплеет, а в том, что нарушен естественный механизм формирования климата разрушаемыми экосистемами планеты. Но 
«безголосых» ученых-экологов не слышат или не хотят слышать «глухие» политические деятели. Исходный вариант Парижского договора, который должен заменить Киотский протокол, подписан, но его действия начнутся с 2020 года. Четыре года уйдет на то, чтобы страны-участницы ратифицировали этот договор. Кроме того, страны-участницы обязались каждые 5 лет пересматривать и корректировать план действий. Одним из самых сложных вопросов на переговорах стало принятие новой дифференциации стран в определении, кто будет предоставлять финансовую и техническую помощь, а кто ее будет получать. Развивающиеся страны будут иметь финансовую поддержку при внедрении соответствующих технологий для сокращения уровней выбросов ПГ в атмосферу. Украина во время переговоров отстояла свой особый статус страны с переходной экономикой, чтобы иметь доступ к международной поддержке в развитии топливно-энергетических и экологических технологий. Следует также отметить, что услышав о возможном «финансовом дождике» швейцарская компания «Climeworks» и канадская «Carbon Engineering» уже разрабатывают технологии по сбору $\mathrm{CO}_{2}$ из воздуха для возможной его продажи парниковым хозяйствам или даже для производства углеводородных топлив. Указанные технологии, как и технологии по улавливанию $\mathrm{CO}_{2}$ из дымовых газов энергетических установок, практически не смогут оказать сколь-нибудь заметное влияние на снижение уровня глобального парникового эффекта.

Реальные истоки накопления диоксида углерода и супертоксикантов в тропосфере Земли

На рис. 5 приведены данные по увеличению концентрации $\mathrm{CO}_{2}$, а, соответственно, уровней его содержания в тропосфере и роста ССПТВ за период с 1970 по 2015 гг. Из представленных данных видна также положительная корреляционная связь между увеличением концентраций $\mathrm{CO}_{2}$ в тропосфере и ростом численности населения Земли.

Следует при этом особо отметить, что влияние стационарной теплоэнергетики и транспорта как по уровням выбросов $\mathrm{CO}_{2}$ в тропосферу с продуктами сжигания топлив, так и по объемам производства энергии на Земле не являются значимыми. А вот уровни супертоксикантов, выбрасываемых в ОС с продуктами сжигания топлив, как раз способствуют угнетению и деградации фотосинтезирующих систем и биосферы планеты в целом. Поэтому, без экологизации хозяйственной деятельности будущего у человечества нет и надо срочно менять подходы к решению важнейшей проблемы современности - глобального потепления климата на Земле. Рост антропогенно-экологического воздействия численно возросшего человечества на ПРИРОДУ резко обострил множество предельно опасных для живой материи и человека явлений: ежегодно на Земле исчезают от 100 до 1000 видов биоты из миллиона; не исключено появление глобальной озоновой дыры (из-за переохлаждения стратосферы); на планете голодают более 10 \% населения; практически достигнуты пределы использования объемов пресной воды и площадей обрабатываемых земель; резкий рост техногенных пустынь; исчезают лесные экосистемы - важнейшие природные источники аккумулирования $\mathrm{CO}_{2}$ в тропосфере и т.д. [1-3, 6-16]. Поэтому своевременным, научно обоснованным и предельно важным для Украины в стратегическом векторе решения современной проблемы глобального потепления климата Земли было бы восстановление к 2030 г. (при финансовой поддержке Евросоюза) лесных экосистем Карпатских гор на своей территории с учетом воссоздания их природообразующих и климатостабилизирующих функций.

На рис. 6 представлены сравнительные данные по уровням накопления $\mathrm{CO}_{2}$ в тропосфере, а также - уровням роста эмиссии $\mathrm{CO}_{2}$ и супертоксикантов (СТ) в тропосферу с продуктами сжигания топлив.

Однако, на международном уровне (в основном политиками) принимаются дезориентирующие решения, направленные на узкотехнологическое снижение выбросов $\mathrm{CO}_{2}$ в тропосферу, в том числе, путем его улавливания из дымовых газов энергоустановок, что лишено здравого смысла, учитывая, что рост индустриальных выбросов $\mathrm{CO}_{2}$ составляет менее $10 \%$ от уровня его накопления в тропосфере (рис. 6). Если к 2020 г. будут снижены мировые уровни индустриальных выбросов $\mathrm{CO}_{2}$ на 20\% (в соответствии с ранее принятыми с международнополитическими решениями), то к этому сроку растущая ССПТВ будет как-бы ниже на $0,01^{\circ} \mathrm{C}$, а стоимость внедрения технологий такого улавливания $\mathrm{CO}_{2}$ может составлять более 100 млрд. долл. США в год. Это пример одной из глобальнополитических афер XXI века и начало на бесконечно безнадежном пути замены естественных биосферных регуляторов климата - искусственными, т.е. техносферой. И самое страшное - уничтожение лесов, являющихся мощным природным накопителем $\mathrm{CO}_{2}$ и, соответственно, фактором формирования устойчивого климата на Земле. Поэтому необходимо ставить совершенно другую стратегическую задачу - необходимо восстановление естественной окружающей природной среды, ее регуляторных и климатообразующих функций на всей территории планеты. Таким образом, именно человек, ввиду большой численности и огромного 
надбиологического потребления природных ресурсов, а также роста (более чем на порядок) уровней загрязнения ОС супертоксикантами, стал по существу главной причиной нарушения равновесия в природе. Все это привело к разбалансировке климатической системы Земли: снижению биотической регуляции параметров ОС, уменьшению сто- ков $\mathrm{CO}_{2}$ и его накоплению в тропосфере, усилению парникового эффекта и росту ССПТВ. Выход же из кризиса видится в изменении вектора развития экономики и экологизации всех сфер человеческой деятельности, включая восстановление важнейших природных регуляторов экосферы, в том числе климата планеты.

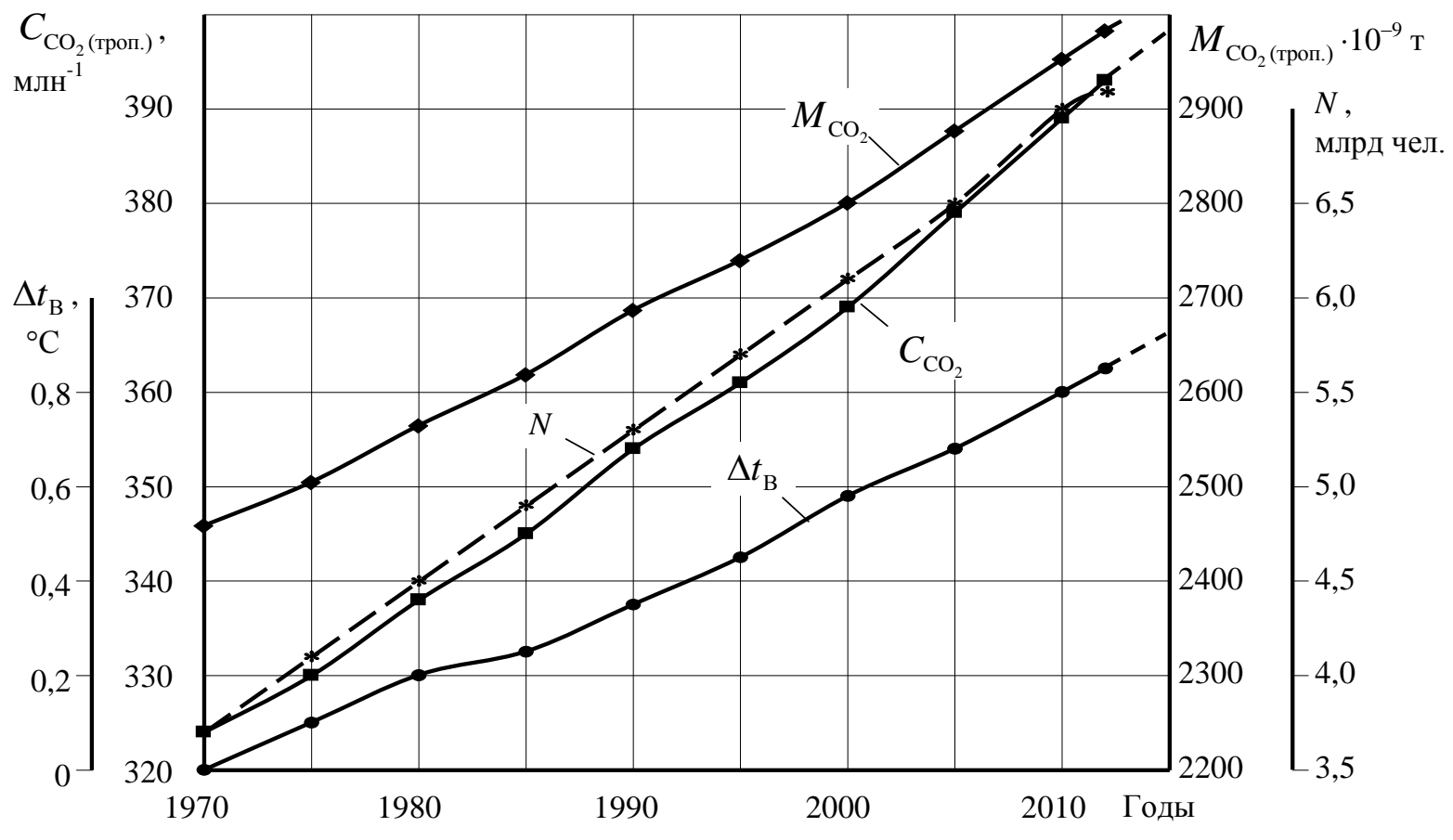

Рис. 5. Изменение параметров тропосферы и роста численности населения планеть Земля по годам, где $M_{\mathrm{CO}_{2}} \approx M_{\text {троп. }} \cdot C_{\mathrm{CO}_{2}} \approx 5 \cdot 10^{15} \cdot C_{\mathrm{CO}_{2}} \cdot\left(\eta_{\mathrm{CO}_{2}} / \eta_{\mathrm{B}}\right) ; \eta_{\mathrm{CO}_{2}}, \eta_{\mathrm{B}}$ - молекулярная масса CO $_{2}$ и воздуха; $\Delta t_{\mathrm{B}}-$ рост ССПТВ; $N$-изменение численности населения Земли

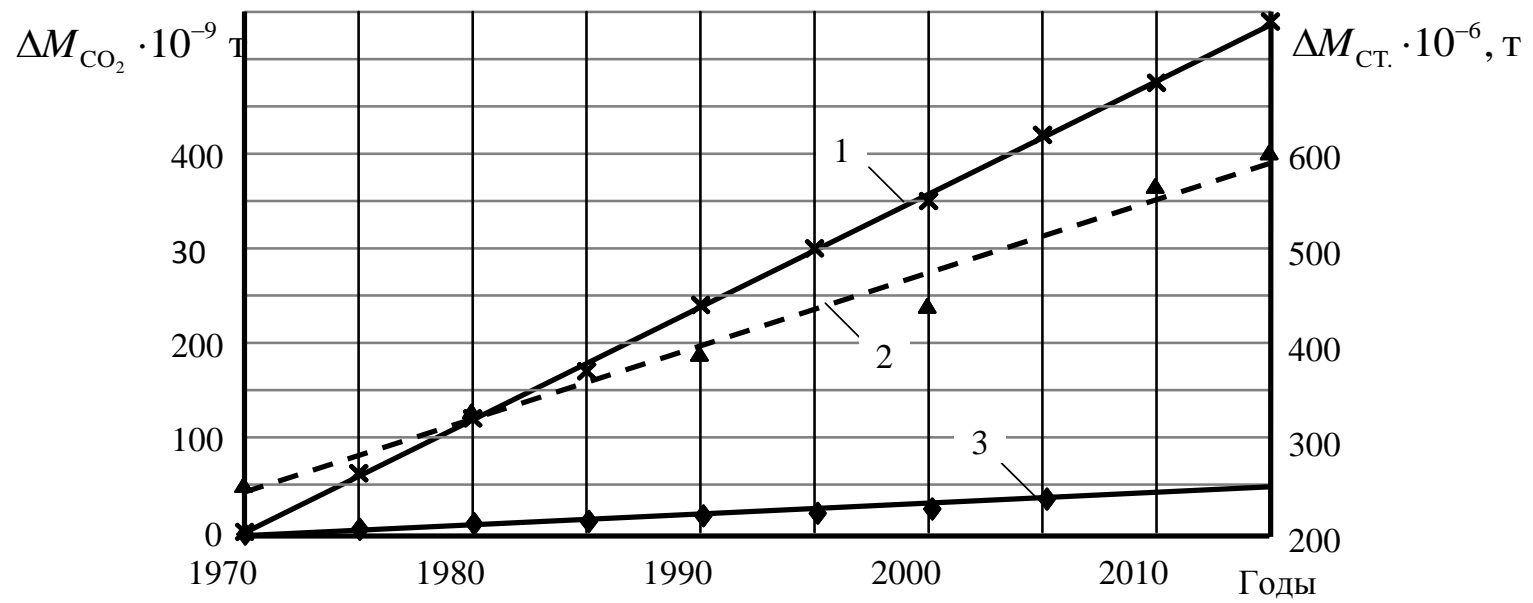

Рис. 6. Прирост уровней содержания $\mathrm{CO}_{2}$ в тропосфере (1), увеличение уровней эмиссии супертоксикантов (2) и $\mathrm{CO}_{2}$ (3) с продуктами сжигания топлив по годам 


\section{Заключение}

1. Для стабилизации климата на планете и оздоровления ОС, а также - обеспечения дальнейшего развития цивилизации или, вернее, - выживания человеческого общества, необходимо осознать, что дальнейшее развитие общества сверхпотребления приведет к глобальной экологической катастрофе и к коллапсу цивилизации; требуются глубокие качественные изменения: технологий производств, стереотипов ценностей и обеспечение права людей на безопасную среду жизни; необходима замена мира ресурсоемкого, металло-нефтяного, машинно-технологического миром наукоемким, информационным, биотехнологическим. Без этого невозможно преодолеть топливно-энергетический и эколого-климатический кризисы.

2. Все крупные сдвиги в глобальном климате являются следствием орбитально обусловленных изменений в радиационном балансе Земли. Стабилизация климата в истории Земли имела биотическую природу. Важнейшей составляющей современного потепления климата является хозяйственная деятельность все увеличивающейся численности человечества, включая существенное повышение уровней неэффективного использования природных ресурсов, а также - предельно опасное загрязнение среды жизни супертоксикантами. Bсе это привело к угнетению, деградации, разрушению и уничтожению систем биосферы, изменению глобальных потоков углерода и кислорода, снижению стоков диоксида углерода и накоплению его в тропосфере и, как следствие, - к глобальному потеплению климата. Поэтому реальная экономизация и экологизация всех сфер человеческой деятельности должны стать основным социально-экономическим мотивом дальнейшего развития, $\mathrm{a}$, возможно, и существования человеческого общества. Для этого потребуются объединенные усилия всех наций планеты, единство науки, экономики, политики и т.д. При бездействии человечества планета Земля может перейти в новый режим функционирования.

3. Основным вектором поддержания пригодного для жизни климата Земли является: оздоровление экосферы, восстановление видового разнообразия и климатообразующих функций биоты на большей части территории планеты, т.е. нужны принципиальные изменения в стратегии природопользования. Ресурсо- и энергосбережение - основной путь экономизации и экологизации экономики. Международным организациям (OOH, Совету Европы и т.д.), общественным организациям и религиозным конфессиям необходимо совместно подготовить и реализовать международномотивационную программу по снижению отрица- тельных проблем технократической цивилизации и восстановлению природных стабилизаторов климата. Сегодня наша планета Земля и человеческое общество вступили в совершенно новый этап своего развития, когда только коллективный Разум и общие целенаправленные усилия позволят избежать глобальной экологической катастрофы. Фактор времени и максимальное использование достижений науки и техники играют здесь решающую роль. Назад в пещеры пути нет - нас слишком много! Мы «обречены» на прогресс, но в этом и заключается наша надежда, наш оптимизм. Именно в общем согласии и решении возникших социоэкологических проблем есть Мудрость и Будущее всего человечества.

\section{Список литературы:}

1. Подрезов О.А. Изменение современного климата / О.А. Подрезов // Вестник КРСУ. - 2009. - Т. 9, № 1. - C. 123-137. 2. Горшков В.Г. Природа наблюдаемой устойчивости климата Земли /В.Г. Гориков, А.М. Макарьева // Геоэкология, инженерная геология, гидрогеология, геокриология. - 2006. - № 6. - С. 483-495. 3. Монин А.С. Новое о климате / А.С. Монин, А.А. Берестов // Вестник РАН. - 2005. - T.75, № 2. -С. 126-138. 4. Имбри Дж. Тайны ледниковых эпох / Дж. Имбри, К.П.Имбри. - М.: Прогресс, 1988. - 264 с. 5. Мелешко В.П. Потепление климата: причины и последствия / В.П. Мелешко // Химия и жизнь. - 2007. - № 4. - С.1-7. 6. Гулев С.К. Глобальное потепление продолжается / С.К. Гулев, В.М. Катџов, О.Н. Соломина // Вестник РАН. - 2008. - T. 78, № 1. - C. 20-27. 7. Морев С.Ю. Климатические проблемы ХХІ века / С.Ю. Морев // Успехи современного естествознания. 2012. - № 3. - С. 65-68. 8. Канило П.М. Автотранспорт. Топливно-экологические проблемы и перспективы: Монография / П.М. Канило. - Харьков: Харьков. наи. автодор. ун-т. - 2013. - 272 с. 9. Канило П.М. Глобальное потепление климата. Антропогенно-экологическая реальность: монография / П.М.Канило. - Харьков: ХНАДУ, 2015. - 312 c. 10. Семиноженко В.П. Энергия. Экология. Будущее: Учебник / В.П. Семиноженко, П.М. Канило, В.Н. Остапчук, А.И. Ровенский. - Харьков: Прапор, 2003. - 464 c. 11. Макарьева А.М. Парниковый эффект и проблема устойчивости среднеглобальной температуры земной поверхности / А.М. Макарьева, В.Г. Горшков // Доклады РАН. - 2001. - Т376, № 6. - С. 810-814. 12. Канило П.М. Влияние автотранспорта и энергетики на потепление климата / П.М. Канило, Н.В. Внукова, К.В. Костенко // Автомоб. транспорт: сб. научн. тр. 2010. - Bыn. 48. - C. 170-175. 13. Канило П.М. Антропогенно-экологические составляющие глобального потепления климата / П.М. Канило, К.В. Костенко // Проблемы машиностроения. - 2010. - Т. 13., №. 4 - С. 68-76. 14. Кондратьев С.М. Климат Земли и «Протокол Киото» / С.М. Кондратьев, К.С. Демьрчан // Вестник РАН. 2001. - T.71, № 11. -С. 1002-1009. 15. Лосев К.С. Парадоксы борьбы с глобальным потеплением / К.С. Лосев // Вестник РАН. - 2009. - T. 79, № 1. - С. 36-40. 16. Канило П.М. Тепловая энергетика, ДВС и глобальное потепление климата / П.М.Канило, А.П.Марченко, И.В. Парсаданов // Двигатели внутреннего сгорания: сб. научн. тр. - Харьков: НТУ «ХПИ», 2015. - № 2. - С. 57 68. 


\section{Bibliography (transliterated):}

1. Podrezov, O.A., (2009), Changing the current climate [Izmenenie sovremennogo klimata], Bulletin KRSU, vol. 9, № 1, pp. 123-137. 2. Gorshkov, V.G., Makarieva, A.M., (2006), The nature of the ob served global climate stability [Priroda nabljudaemoj ustojchivosti klimata Zemli], Geoecology, engineering geology, hydrogeology, geocryology, № 6, pp. 483- 495. 3. Monin, A.S., Berastau, A.A., (2005), New about climate [Novoe o klimate], Herald of the RAN, vol. 75, № 2, pp. 126-138. 4. Imbrie, J., Imbri, K.P.,(1988), Secrets of glacial [Tajny lednikovyh jepoh], Progress, Moskov, 264 p. 5. Myaleshka, V.P., (2007), Climate Change: Causes and Consequences [Poteplenie klimata: prichiny i posledstvija], Chemistry and life, № 4, pp. 1-7. 6. Gulev, S.K., Katze, V.M., Solomin, O.N.,(2008), Global warming continues [Global'noe poteplenie prodolzhaetsj], Herald of the RAN, vol. 78, № 1, pp. 20-27. 7. Morev, S.Y., (2012), Climatic problems of the XXI century [Klimaticheskie problemy XXI veka], Successes of modern science, № 3, pp. 65-68. 8. Kanilo, P.M. (2013), Transport. Fuel and environmental problems and prospects: Monograph [Toplivno-jekologicheskie problemy $i$ perspektivy: Monografija], Kharkov National University Road, Kharkov, 272 p. 9. Kanilo, P.M.,(2015), Global warming. Man-ecological reality: monograph [Global'noe poteplenie klimata. Antropogennojekologicheskaja real'nost': monografija], HNADU, Kharkov, 312 p. 10. Seminozhenko, V.P., Kanilo, P.M., Ostapchuk, V.N., Rivne A.I.,
(2003), Energy. Ecology. Future: Textbook [Jenergija. Jekologija. Budushhee: Uchebnik], Prapor, Kharkov, 464 p. 11. Makarieva, A.M., Gorshkov, V.G.,(2001), The greenhouse effect and the problem of stability of the global mean temperature of the earth's surface [Parnikovyj jeffekt $i$ problema ustojchivosti sredneglobal'noj temperatury zemnoj poverhnosti], Reports of Academy of Sciences, vol.376, №6, pp. 810-814. 12. Kanilo, P.M., Vnukovo, N.V., Kostenko, K.V., (2010), Influence of transport and energy on global warming, [Vlijanie avtotransporta i jenergetiki na poteplenie klimata], Road Transport: collection of scientific works, vol. 48. pp. 170-175. 13. Kanilo, P.M., Kostenko, K.V., (2010), Anthropogenicenvironmental components of global climate, [Antropogennojekologicheskie sostavljajushhie global'nogo poteplenija klimata], Problems of mechanical engineering, vol. 13., №. 4, pp. 68-76. 14. Kondratiev, S.M., Demyrchan, K.S., (2001), The Earth's climate and the "Kyoto Protocol" [Klimat Zemli $i$ "Protokol Kioto»], Herald of the RAN, vol.71, № 11. pp. 1002-1009. 15. Losev, K.S., (2009), Paradoxes of the fight against global warming, [Paradoksy bor'by $s$ global'nym potepleniem], Herald of the RAN, vol. 79, № 1, pp. 3640. 16. Kanilo, P.M., Marchenko, A.P., Parsadanov, I.V., (2015), Thermal energy, combustion engine and global climate [Teplovaja jenergetika, DVS i global'noe poteplenie klimata], Internal combustion engines: a collection of scientific papers, NTU «KhPI», Kharkov, № 2. pp. 57-68.

Поступила в редакияию 07.07.2016 2.

Канило Павел Макарович - доктор техн. наук, профессор, Институт проблем машиностроения им. А.Н. Подгорного НАН Украины, Харьков, Украина.

\section{ЛЬОДОВИКОВІ ЕПОХИ І ГЛОБАЛЬНЕ ПОТЕПЛІННЯ КЛІМАТУ П.М. Канило}

Наводяться короткі історичні аспекти з історії вивчення льодовикових епох, змін клімату Землі і народження астрономічної теорії. Наголошується, що сучасний міжльодовиковий період за астрономічними канонами повинен був закінчуватися в найближчому тисячолітті і починатися похолодання. Однак, приблизно з 1970 р, на Землі відбувається глобальне потепління клімату. Обгрунтовується висновок, що сучасне потепління клімату - це антропогенно-екологічна реальність, пов'язана з різким збільшенням чисельності людства і його хижацьким ставленням до ПРИРОДИ, істотним підвищенням рівнів неефективного використання природних ресурсів і гранично небезпечним забрудненням середовища життя супертоксікантами, з деградацією, руйнуванням і знищенням систем біосфери, включаючи глобальну біоту, $\mathrm{i}$ призводять, відповідно, до зниження якості їх функціонування, в тому числі, біопродуктивності, середовищеутворюючих і кліматостабілізіруючих функцій.

\section{THE GLACIER EPOCHS AND GLOBAL WARMING \\ P. Kanylo}

Provides brief historical aspects of studying glacial epochs, changes in the Earth's climate and astronomical theory. It is noted that modern interglacial for astronomical canons should end at the nearest Millennium and start cooling. However, since about 1970, occurs on the Earth global warming. The article substantiates the conclusion that modern global warming is anthropogenic environmental reality, linked to the sharp increase in humanity and its predatory nature, significant increased levels in the inefficient use of natural resources and extremely dangerous pollution Wednesday, supertoxicants life with the degradation, destruction and destruction of the biosphere systems, including the global biota, and lead, respectively, to reduce the quality of their operation, including bio-productivity, own ecological resources and climate-stabilizing functions. 